\title{
Identification of putative secretory and membranous proteins of Chlamydia trachomatis using bioinformatics tools
}

\author{
Prashant K Mishra', Renu Pandey', Uma Chaudhry², Daman Saluja ${ }^{1 *}$ \\ From 2nd International Science Symposium on HIV and Infectious Diseases (HIV SCIENCE 2014) \\ Chennai, India. 30 January - 1 February 2014
}

\section{Background}

Intuitive understanding of hypothetical genes's signal peptide, transmembrane helix $(\mathrm{TH})$ domain and LipoP box of any pathogenic microorganisms is a prerequisite for the rational development of drugs and vaccine candidates. A protein harboring these sequences may serve as receptor and conveyer for various biostimulations generated during host-pathogen interaction. Identification and annotation of these proteins may help in designing of novel drug or developing new vaccine candidates to control CT infections.

\section{Methods}

We have retrieved whole sequence of CT serovar D/UW3/CX from NCBI database. To identify secreted proteins, $\mathrm{TH}$ domain and lipoP box, we have exploited the following online softwares: sigpred (http://bmbpcu36.leeds.ac. uk/cgi bin/sig_pred), siglanlP4.0 (http://www.cbs.dtu.dk/ services/SignalP), TMpred (http://www.ch.embnet.org/ software/TMPRED_form.html), TMHMM (http://www. cbs.dtu.dk/services/TMHMM/) and LipoP box (http:// www.cbs.dtu.dk/services/LipoP/).

\section{Results}

The present study focused on the 336 HPs of CT to find out signal peptide, TH domain and lipoP box. Out of 336 HPs. Forty proteins have lipoP box and five proteins (CT149, CT605, CT623, CT823 and CT858) have signal peptide as well as TH domain. Additionally, among five, four proteins (CT149, CT623, CT823 and CT858) also have lipoP box. Harboring TH domain sequences suggests

\footnotetext{
* Correspondence: dsalujach59@gmail.com

'Dr. B. R. Ambedkar Center for Biomedical Research, University of Delhi, Delhi- 110007, India

Full list of author information is available at the end of the article
}

that they may have either membrane spanning, extracellular or intracellular domain which may help in host-pathogen interactions and/or signal transduction. It is also possible that these proteins may be secreted and thereby induces host immune responses but it will need further validation.

\section{Conclusion}

We consider that CT149, CT605, CT623, CT823 and CT858 may be secreted outside the pathogen and should be explored further to understand the pathogenesis of CT.

\section{Authors' details}

${ }^{1}$ Dr. B. R. Ambedkar Center for Biomedical Research, University of Delhi, Delhi- 110007, India. ${ }^{2}$ Bhaskaracharya College of Applied sciences, University of Delhi, Delhi-110075, India.

Published: 27 May 2014

\section{doi:10.1186/1471-2334-14-S3-P6}

Cite this article as: Mishra et al:: Identification of putative secretory and membranous proteins of Chlamydia trachomatis using bioinformatics tools. BMC Infectious Diseases 2014 14(Suppl 3):P6.

Submit your next manuscript to BioMed Central and take full advantage of:

- Convenient online submission

- Thorough peer review

- No space constraints or color figure charges

- Immediate publication on acceptance

- Inclusion in PubMed, CAS, Scopus and Google Scholar

- Research which is freely available for redistribution 